\title{
Audit Sistem Informasi E-Kinerja Dinas Kependudukan Dan Pencatatan Sipil Kota Denpasar
}

\author{
Ida Bagus Agung Eka Mandala Putra ${ }^{1}$, Rukmi Sari Hartati ${ }^{2}$, Yoga Divayana ${ }^{3}$ \\ Submission: 09-03-2020, Accepted: 18-06-2020
}

\begin{abstract}
Civil Servants or abbreviated as PNS represent countries that have a role in carrying out their duties to achieve the goals of the State. Contributions made by civil servants through performance affect the progress and achievement of a government agency. Staffing management at government agencies has been processed by utilizing information technology. E-Kinerja is a breakthrough by the government to measure the productivity of civil servants against responsibilities towards the main tasks and functions in achieving the objectives of government. The E-Performance information system each civil servant processes the employee performance target data input process, which is an agenda to be carried out by PNS, based on the PNS Work Behavior. The E-Performance information system of each civil servant process the employee performance targets the input data process, which is an agenda to be carried out by civil servants, based on the PNS Work Behavior. The capability of the E-Kinerja information system for staffing management needs to be evaluated. E-Performance information system audits can provide an overview, evaluation and identification of the use of information technology can provide results in terms of staffing management. COBIT 5 Framework is a collection of procedures that can meet the needs of governance and management to achieve the goals of an organization. In this research the $E$ Kinerja information system reaches an average value of 3.67 at level 4 (Predictble Process). Indicates that the planning of the $\mathbf{E}$ Kinerja information system at the Denpasar City Population and Civil Registry Office has achieved the expected goals.
\end{abstract}

Key words : E-Performance, Audit information system, Denpasar Population and Civil Registry Office, Cobit 5.

Intisari- Pegawai Negeri Sipil atau disingkat PNS merupakan abdi negara yang memiliki peran dalam menjalankan tugas untuk mencapai tujuan Negara. Kontribusi yang diberikan oleh PNS melalui kinerja berpengaruh terhadap kemajuan dan pencapaian suatu instansi pemerintah. Manajemen kepegawaian pada instansi pemerintah telah diolah dengan memanfaatkan teknologi informasi. E-Kinerja merupakan terobosan pemerintah untuk mengukur produktivitas PNS terhadap tanggung jawab terhadap tugas pokok dan fungsi dalam mencapai tujuan dari instansi pemerintah. Pada sistem informasi E-Kinerja tersebut setiap PNS melakukan proses input data SKP (Sasaran Kinerja Pegawai) yang merupakan agenda yang akan dikerjakan oleh PNS, berdasarkan Perilaku Kerja PNS. Peran sistem berbasis

${ }^{1}$ Mahasiswa, Program Pasca Sarjana, Manajemen Sistem Informasi dan Komputer Fakultas Teknik Universitas Udayana, Jln. P.B. Sudirman, Denpasar, Bali 80232 INDONESIA (tlp: 0361-239599; e-mail: eka.mandala@student.unud.ac.id)

2, 3 Dosen, Program Pasca Sarjana, Magister Teknik Elektro Fakultas Teknik Universitas Udayana, Jln. P.B. Sudirman, Denpasar, Bali 80232 INDONESIA (telp: 0361-239599 e-mail: ${ }^{2}$ rukmisari@unud.ac.id,3yoga@unud.ac.id) elektronik dapat membantu instansi pemerintah khususnya Dinas Kependudukan dan Pencatatan Sipil Kota Denpasar dalam memantau kinerja PNS untuk memastikan berjalannya tugas pokok dan fungsi serta tercapainya tujuan instansi pemerintah tersebut. Kemampuan sistem informasi E-Kinerja terhadap manajemen kepegawaian perlu kiranya dilakukan evaluasi. Audit sistem informasi E-Kinerja dapat memberikan gambaran, evaluasi dan identifikasi terhadap pemanfaatan teknologi informasi dapat memberikan hasil dalam hal manajemen kepegawaian. Framework COBIT 5 merupakan kumpulan prosedur yang dapat memenuhi kebutuhan tata kelola dan manajemen untuk menggapai tujuan suatu organisasi. Pada peneltian ini sistem informasi E-Kinerja menunjukan rata-rata nilai 3.67 berada pada level 4 (Predictble Process). Menandakan perencanaan sistem informasi E-Kinerja pada Dinas Kependudukan dan Pencatatan Sipil Kota Denpasar telah mencapai tujuan yang diharapkan.

Kata Kunci- Kinerja, Audit Sistem Informasi, E-Kinerja, Dinas Kependudukan dan Pencatatan Sipil Kota Denpasar, COBIT 5.

\section{PENDAHULUAN}

Penerapan teknologi informasi telah dilakukan diberbagai instansi pemerintah dalam pengolahan data dan mendukung proses manajemen. Transparansi, efektifitas dan efisiensi menjadikan pemerintah melakukan investasi tata kelola teknologi informasi untuk dapat memberikan hasil yang maksimal [1]. Dengan adanya kebijakan E-Government merupakan upaya untuk penyelenggaraan kepemerintahan dengan memanfaatkan media elektronik berorientasi dalam mengoptimalkan kualitas layanan publik dengan efektif serta efisien [2]. Sumber daya yang dimiliki oleh pemerintah merupakan aset penting dalam mencapai tujuan pemerintah. Kinerja Pegawai Negeri Sipil atau yang sering disebut dengan PNS merupakan suatu hasil kerja yang diraih pada setiap Pegawai Negeri Sipil dalam organisasi/unit berdasarkan sasaran kinerja pegawai atau yang disebut dengan SKP dan Perilaku kerja [3].

SKP (Sasaran Kinerja Pegawai) merupakan agenda kerja dengan sasaran yang akan di capai oleh seorang Pegawai Negeri Sipil pada setiap tahunnya. Pemerintah mengoptimalkan kinerja PNS yang telah ditargetkan sesuai SKP, sehingga PNS bertanggung jawab dan menyelesaikan tugas pokok dan fungsinya dengan baik. Perilaku kerja merupakan suatu kegiatan PNS yang dilakukan untuk mencapai SKP, dengan tujuan merealisasikan harapan pemerintah. Optimalisasi kinerja PNS pada setiap tugas pokok dan fungsi dalam SKP yang telah disepakati, serta konsistensi perilaku kerja akan menghadirkan hasil kinerja yang baik dalam pemerintahan demi kepentingan masyarakat Indonesia.

Dinas Kependudukan dan Pencatatan Sipil Kota Denpasar adalah suatu organisasi perangkat daerah pemerintah Kota 
Denpasar yang memiliki pekerjaan pokok dan fungsi dalam Administrasi Kependudukan beserta Pencatatan Sipil untuk warga kota Denpasar [4]. Pada Dinas Kependudukan dan Pencatatan Sipil Kota Denpasar memiliki jumlah pegawai sebanyak 81 Pegawai Negeri Sipil, dengan rincian Kepala Dinas sejumlah 1 orang, Sekretaris Dinas dan Kepala Bidang dengan jumlah 5 orang, Kepala Sub Bagian dan Kepala Seksi sebanyak 14 orang serta Staf PNS dengan jumlah 61 orang. Manajemen kepegawaian pada Dinas Kependudukan dan Pencatatan Sipil Kota Denpasar ditangani oleh Kepala Sub Bagian Umum Kepegawaian. Pegawai Negeri Sipil setiap tahunnya membuat Sasaran Kinerja Pegawai yang akan dikerjakan oleh PNS selama satu tahun periode manajemen. Sasaran Kinerja Pegawai akan dicapai berdasarkan perilaku kerja PNS yang akan di masukan kedalam suatu sistem informasi E-Kinerja. Sistem informasi e-kinerja merupakan tata kelola dan strategi penghimpunan, penyusunan, analisis penyampaian, pendayagunaan dan dokumentasi data akan kinerja PNS dengan terintegrasi [3].

Pelaksanaan sistem informasi E-Kinerja tentunya perlu dievaluasi melalui audit sistem informasi yang merupakan suatu langkah yang dapat dilakukan pemerintah, untuk mengukur kinerja sistem informasi E-Kinerja pada Dinas Kependudukan dan Pencatatan Sipil Kota Denpasar. Kerangka kerja audit yang diterapkan didalam penelitian ini yaitu (Control Objectives for Information and Related Technology) COBIT 5 yang menggambarkan kerangka kerja komperhensif, serta dapat memenuhi kebutuhan tata kelola serta manajemen untuk dapat mengoptimalkan kinerja TI. Tujuan dari penelitian ini untuk mengevaluasi kinerja sistem informasi EKinerja pada Dinas Kependudukan dan Pencatatan Sipil Kota Denpasar, serta mengoptimalkan manfaat teknologi informasi dalam manajemen kepegawaian. Memastikan bahwa penerapan IT pada manajemen kinerja PNS memberikan hasil yang optimal.

\section{TINJAUAN PUSTAKA}

\section{A. Audit Sistem Informasi}

Audit sistem informasi yakni serangkaian prosedur secara sistematis dalam mencapai dan menilai bukti rasional atas aset sistem informasi dengan orientasi dalam penetapan tingkat konsistensi antara sistem informasi dengan kriteria standar yang ditetapkan [5].

\section{B. Sistem Informasi E-Kinerja}

Sistem informasi E-Kinerja merupakan tata kelola dan mekanisme pengumpulan, pengolahan, analisa, penyajian dan dokumentasi kinerja Pegawai Negeri Sipil dengan terintergrasi [3]. Sistem pengelolan kinerja Pegawai Negeri Sipil merupakan prosedur sistematis yang didalamnya terdapat perencanaan unjuk kerja, pemantauan, aktualiasi, penilaian kinerja dan pembinaan terhadap kinerja.

\section{Pengukuran Kinerja Pegawai Negeri Sipil}

Komponen pembandingan kinerja yang dilaksanakan Pegawai Negeri Sipil dilihat berdasarkan SKP dan Perilaku Kerja. Sasaran kinerja pegawai merupakan agenda kerja dan orientasi yang wajib digapai oleh Pegawai Negeri Sipil. Pengertian perilaku kerja adalah sikap, perbuatan dan kegiatan yang dijalankan oleh Pegawai Negeri Sipil menurut ketentuan
Undang-Undang yang berlaku [3]. Pertimbangan kinerja Pegawai Negeri Sipil dilaksanakan dengan cara menghimpun nilai SKP dengan nilai perilaku kerja. Kriteria pemeringkatan kinerja Pegawai Negeri Sipil antara lain :

1. Sangat Baik, dengan nilai kinerja Pegawai Negeri Sipil antara seratus sepuluh $(110) \leq \mathrm{X} \leq$ seratus dua puluh (120).

2. Baik, dengan nilai kinerja Pegawai Negeri Sipil antara Sembilan puluh (90) $\leq X \leq$ seratus dua puluh (120).

3. Cukup, apabila kinerja Pegawai Negeri Sipil mencapai nilai antara tujuh puluh (70) $\leq \mathrm{X} \leq$ Sembilan puluh (90).

4. Kurang, apabila kinerja Pegawai Negeri Sipil mendapat nilai antara lima puluh $(50) \leq \mathrm{X} \leq$ tujuh puluh (70).

5. Sangat Kurang, nilai kinerja Pegawai Negeri Sipil mencapai < lima puluh (50).

\section{Pengertian PNS (Pegawai Negeri Sipil)}

Bersumber pada Undang-Undang Republik Indonesia Nomor 43 Tahun 1999, menjelaskan bahwa Pegawai Negeri merupakan komponen aparatur negara, abdi kepada negara dan abdi kepada masyarakat setia dan taat pada Pancasila serta Undang-Undang Dasar Tahun 1945, negara bersama pemerintah, menjalankan tugas pemerintahan dengan pembangunan [6]. Menurut Undang-Undang Republik Indonesia Nomor 5 Tahun 2014, Pegawai Negeri Sipil adalah Warga Negara Indonesia menepati peraturan tertentu, diangkat menjadi Pegawai Aparatur Sipil Negara dengan definitive oleh pejabat pembina kepegawaian dalam menduduki suatu jabatan pemerintah [7]. Fungsi dari Pegawai Negeri Sipil yaitu sebagai berikut:

1. Pelaksana garis haluan publik.

2. Pelayan publik.

3. Perekat serta pemersatu bangsa.

Berikut adalah penjabaran dari Fungsi dan tugas dari Pegawai Negeri Sipil:

1. Mengerjakan kebijakan publik yang dikeluarkan oleh Pejabat Pembina Kepegawaian bersumber pada ketentuan regulasi perundang-undangan.

2. Memberikan pelayanan publik dengan professional dan bernilai.

3. Memperkuat kesatuan dan persatuan NKRI (Negara Kesatuan Republik Indonesia).

\section{E. Pengertian E-Kinerja PNS}

Kinerja merupakan suatu kontribusi pengabdian yang diberikan pada setiap Pegawai Negeri Sipil didalam pemerintahan. Pengertian dari kinerja Pegawai Negeri Sipil merupakan pencapaian PNS terhadap hasil kerja yang telah dilakukan di suatu instansi/organisasi berdasarkan sasaran kinerja pegawai beserta perilaku kerja [3]. Komponen dari kinerja Pegawai Negeri Sipil meliputi sebagai berikut:

1. Indikator kinerja individu, merupakan standar pencapaian kerja yang diperoleh oleh Pegawai Negeri Sipil.

2. Target merupakan beberapa prestasi kerja yang diperoleh pada setiap pengamalan tugas jabatan.

3. Realisasi merupakan hasil akhir yang dicapai sebagian, sesuai atau melampaui target.

\section{F. COBIT 5}


Control Objectives for Information and Related Technology yang biasanya disebut COBIT 5 yakni kerangka kerja secara keseluruhan yang mampu menunjang tata kelola dan manajemen perusahaan untuk menggapai tujuan perusahaan. Kerangka kerja yang sanggup mengoptimalkan nilai teknologi informasi, menegaskan menyelaraskan antara manfaat teknologi informasi pada tingkat resiko serta penggunaan sumber daya. Pada COBIT 5 menyajikan pengelolaan akan teknologi informasi secara keseluruhan beserta komitmen perusahaan dari ujung-ke-ujung serta fungsi teknologi informasi, dan memperhitungkan terkait dengan kepentingan teknologi informasi dari sisi penyelenggara kepentingan internal maupun eksternal [8].

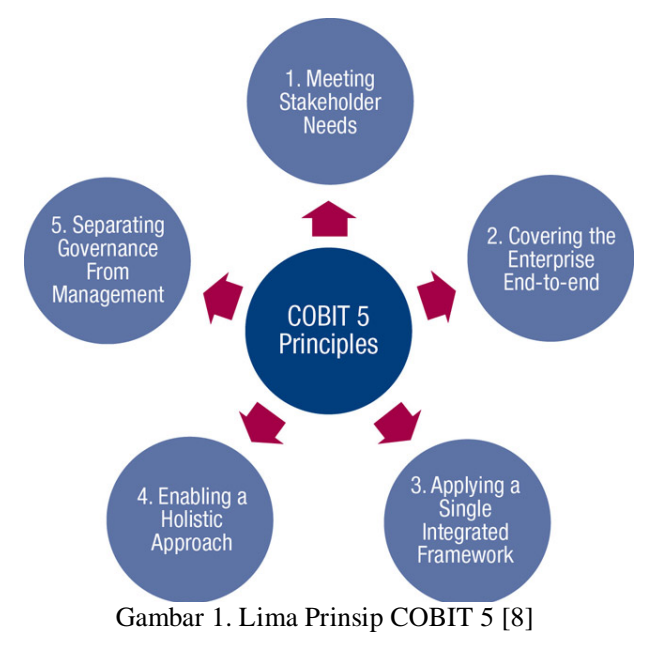

Pada proses COBIT 5 dibedakan menjadi 2 (dua) domain, adalah prosedur tata kelola (Governance) dan manajemen (Management) teknologi informasi pada perusahaan, berikut merupakan penjelasan 2 domain utama tersebut [8]. Pada domain tata kelola diperoleh 5 proses dalam setiap EDM atau yang disebut dengan evaluate, direct and monitor. Sedangkan pada domain management diperoleh 4 domain sejalan dengan aspek tanggung jawab, rancangan, bangun, melaksanakan dan mengawasi, memberikan jangkauan terhadap teknologi informasi secara keseluruhan. Berikut adalah 4 proses yang terdapat pada domain manajemen : APO (Align, Plan and Organise), BAI (Build, Aquire and Implement), DSS (Deliver, Service and Support) dan MEA (Monitor, Evaluate and Assess) [9].

Berdasarkan rangkaian COBIT 5 mencakup proses Capability Model, menuruti kriteria ISO/IEC 15504 Software Engineering Process Assessment standard. Pada Capability Model ada 6 tingkat pencapaian, dimulai dari 0 sampai dengan 5 [10]. Tahapan pencapaian akan ditentukan menurut hasil penilaian dengan domain-domain yang digunakan [11].

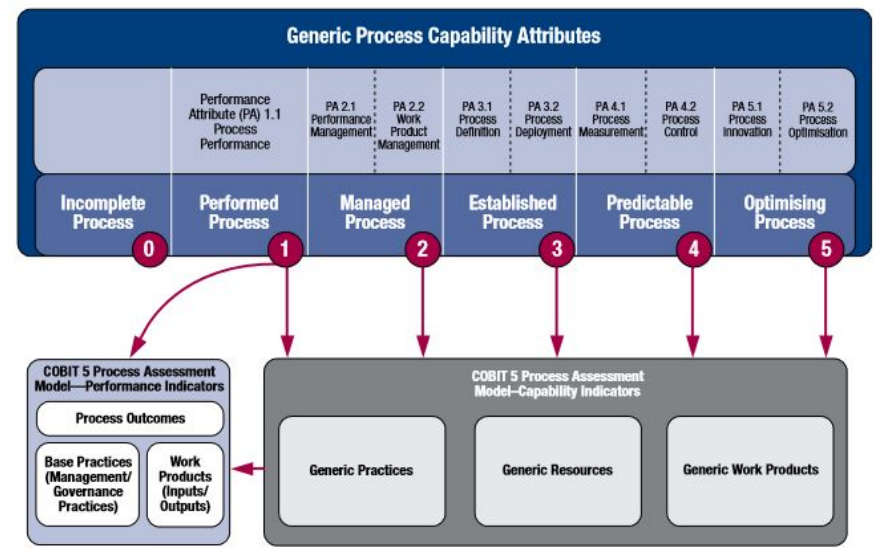

Gambar 2. Proses Capability Model Pada COBIT 5 [8]

TABEL I

TINGKATAN CAPABILITY MODEL

\begin{tabular}{|c|c|}
\hline Tingkatan & Deskripsi \\
\hline $\begin{array}{l}\text { Level } 0: \\
\text { Proses dinyatakan } \\
\text { tidak lengkap }\end{array}$ & $\begin{array}{l}\text { Proses tidak diaplikasikan atau bisa } \\
\text { dikatakan gagal untuk mencapai target. } \\
\text { Untuk level } 0 \text { tidak terdapat atribut }\end{array}$ \\
\hline $\begin{array}{l}\text { Level 1: } \\
\text { Proses Penerapan }\end{array}$ & $\begin{array}{l}\text { Proses yang diterapkan mencapai tujuan. } \\
\text { Pada level ini hanya memiliki kinerja } \\
\text { sebagai atribut. }\end{array}$ \\
\hline $\begin{array}{l}\text { Level } 2 \text { : } \\
\text { Proses yang nyatakan } \\
\text { terkelola }\end{array}$ & $\begin{array}{l}\text { Prosedur dilakukan sebelumnya dapat } \\
\text { dijelaskan saat ini dimana proses ini } \\
\text { dieksekusi dengan teratur (dirancang, } \\
\text { ditinjau dan diselaraskan) dan hasil } \\
\text { kerjanya ditentukan, dikendalikan dan } \\
\text { pemeliharaan yang tepat. Pada level ini } \\
\text { terdapat Manajemen Kinerja dan } \\
\text { Manajemen Hasil Kerja sebagai atribut. }\end{array}$ \\
\hline $\begin{array}{l}\text { Level 3: } \\
\text { Menjelaskan proses } \\
\text { yang mulai terbentuk }\end{array}$ & $\begin{array}{l}\text { Pengelolaan proses yang sebelumnya } \\
\text { dijelaskan, sekarang diaplikasikan } \\
\text { mempergunakan proses yang ditetapkan } \\
\text { dimana dapat mencapai hasil prosesnya. } \\
\text { Tingkat ini memiliki Definisi Proses dan } \\
\text { Penerapan Proses sebagai atribut. }\end{array}$ \\
\hline $\begin{array}{l}\text { Level 4: } \\
\text { Proses yang dapat } \\
\text { diperkirakan }\end{array}$ & $\begin{array}{l}\text { Proses yang direncanakan sebelumnya } \\
\text { dijelaskan sekarang yang dimana } \\
\text { beroperasi dalam batas yang ditentukan } \\
\text { untuk mencapai hasil yang diharapkan. } \\
\text { Level ini memiliki Proses Pengukuran } \\
\text { dan Proses Kontrol sebagai atribut. }\end{array}$ \\
\hline $\begin{array}{l}\text { Level 5: } \\
\text { Proses yang maksimal }\end{array}$ & $\begin{array}{l}\text { Proses yang dapat diprediksi } \\
\text { menjelaskan pada hal sebelumnya yang } \\
\text { dimana dapat ditingkatkan untuk } \\
\text { memenuhi sasaran bisnis saat ini serta } \\
\text { dapat diproyeksikan secara relevan. } \\
\text { Level ini memiliki Proses Inovasi dan } \\
\text { Optimasi sebagai atribut. }\end{array}$ \\
\hline
\end{tabular}




\section{METODOLOGI PENELITIAN}

Berlandaskan masalah beserta tujuan pada penelitian diatas, dapat dilaksanakan tahapan sistematis serta logis. Panduan yang tepat digunakan dengan tujuan memudahkan pemecahan masalah serta dapat memberikan rekomendasi pada penelitian [12].

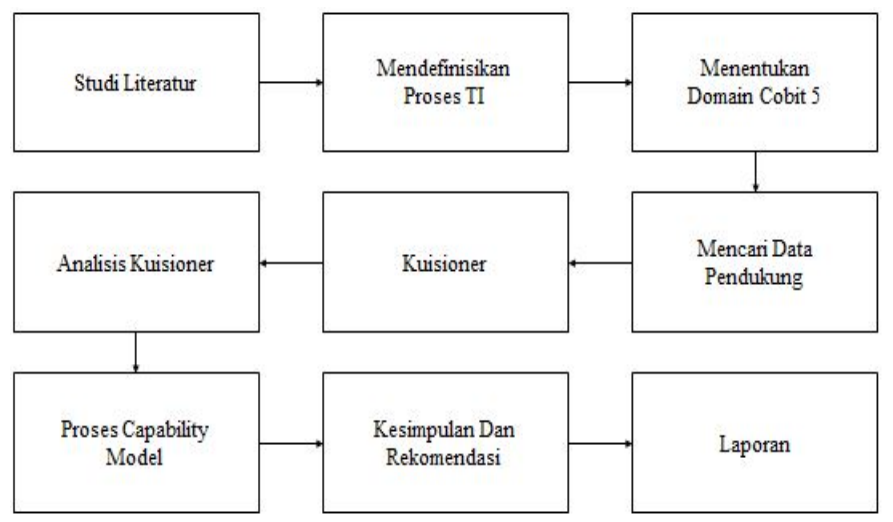

Gambar 3. Tahapan Metodologi Penelitian

Dalam tahapan studi literature merupakan proses mempelajari dan mencari refrensi dari penelitian terkait penerapan COBIT 5. Metode-metode yang tepat dapat digunakan dalam mencapai tujuan dari penelitian. Proses selanjutnya mengidentifikasi Proses TI terhadap penerapan sistem informasi E-Kinerja pada Dinas Kependudukan dan Pencatatan Sipil Kota Denpasar. Setelah proses TI terdefinisi kemudian menentukan domain pada COBIT 5 yang akan dipergunakan untuk mengevaluasi kinerja sistem informasi. Setelah domain COBIT 5 ditentukan proses selanjutnya mencari data pendukung dengan menghimpun data, dokumentasi dan wawancara berhubungan dengan kinerja sistem informasi.

Adapun proses memberikan kuisioner pertanyaan sistematis dan logis menurut domain pada COBIT 5 sebagai arahan dalam proses pengukuran dan evaluasi kepada responden. Hasil dari kuisioner tersebut kemudian dianalisa untuk mengevaluasi dan mengulas jawaban kuisioner yang telah dibagikan serta diolah pada model tingkat kematangan. Setelah hasil dari kuisioner tersebut telah berhasil dianalisa kemudian dilanjutkan dengan proses capability model. Pada tahap ini mendefinisikan pencapaian capability level pada setiap proses TI yang sedang terjadi dengan model tingkat kematangan yang ditargetkan untuk menganalisa tingkat kesenjangan yang terjadi antara proses TI dengan tujuan bisnis [13]. Selanjutnya proses penarikan kesimpulan dan memberikan rekomendasi berdasarkan analisa hasil audit. Kemudian menganjurkan rekomendasi pada E-Kinerja Dinas Kependudukan dan Pencatatan Sipil Kota Denpasar, tentang proses IT yang terjadi. Tahapan berikutnya menyusun laporan audit sebagai bahan evaluasi mengenai kinerja sistem informasi.

\section{HASIL DAN PEMBAHASAN}

Menurut pengamatan pada sistem informasi E-Kinerja Dinas Kependudukan dan Pencatatan Sipil Kota Denpasar. Terdapat titik kritis permasalahan dalam proses TI, berikut merupakan pemetaan titik kritis dan tujuan bisnis [14] [15].
TABEL III

TINGKATAN CAPABILITY MODEL

\begin{tabular}{|l|l|}
\hline Permasalah E-Kinerja & Tujuan Bisnis \\
\hline $\begin{array}{l}\text { Keamanan sistem informasi E- } \\
\text { Kinerja }\end{array}$ & $\begin{array}{l}\text { Manajemen resiko bisnis } \\
\text { (pengamanan aset) (3) }\end{array}$ \\
\hline $\begin{array}{l}\text { Tampilan sisi pengguna tidak } \\
\text { sesuai standar (user friendly) }\end{array}$ & $\begin{array}{l}\text { Optimalisasi fungsi bisnis } \\
(11)\end{array}$ \\
\hline $\begin{array}{l}\text { Penyesuaian PNS dari manual ke } \\
\text { sistem berbasis elektronik }\end{array}$ & $\begin{array}{l}\text { Operasional dan } \\
\text { produktivitas pegawai (14) }\end{array}$ \\
\hline $\begin{array}{l}\text { Kesalahan input SKP dan Perilaku } \\
\text { kerja pada sistem informasi }\end{array}$ & $\begin{array}{l}\text { Operasional dan } \\
\text { produktivitas pegawai (14) }\end{array}$ \\
\hline $\begin{array}{l}\text { Kepatuhan pengguna terhadap } \\
\text { fungsi sistem E-Kinerja }\end{array}$ & $\begin{array}{l}\text { Kepatuhan dengan kebijakan } \\
\text { internal (15) }\end{array}$ \\
\hline Tingkat validasi data & $\begin{array}{l}\text { Optimalisasi fungsi bisnis } \\
(11)\end{array}$ \\
\hline
\end{tabular}

Tujuan bisnis telah melaui proses pemetaan berdasarkan titik kritis permasalahan, selanjutnya pemetaan dengan tujuan TI. Berikut adalah pemetaan tujuan TI menurut tujuan bisnis [16].

TABEL IIIII

PEMETAAN TUJUAN TI

\begin{tabular}{|l|l|}
\hline No & Tujuan Teknologi Informasi \\
\hline 1 & Penyelarasan IT dengan stategi bisnis \\
\hline 2 & $\begin{array}{l}\text { Penyesuaian IT dan pendukung bisnis melalui aturan dan } \\
\text { regulasi secara eksternal }\end{array}$ \\
\hline 4 & Pengelolaan IT terhadap resiko bisnis \\
\hline 7 & Penyampaian Pelayanan melalui IT dengan kebutuhan bisnis \\
\hline 8 & $\begin{array}{l}\text { Penggunaan aplikasi, informasi, dan solusi teknologi secara } \\
\text { memadai }\end{array}$ \\
\hline 9 & Ketepatan IT \\
\hline 10 & $\begin{array}{l}\text { Keamanan informasi, pemerosesan informasi, infrastuktur } \\
\text { dan pengaplikasian }\end{array}$ \\
\hline 12 & $\begin{array}{l}\text { Kemampuan dan dukungan proses bisnis melalui aplikasi } \\
\text { secara terintigrasi dan teknologi didalam proses bisnis }\end{array}$ \\
\hline 15 & Penyampaian IT berdasarkan aturan secara internal \\
\hline 16 & $\begin{array}{l}\text { Kemampuan, motivasi bisnis dan petugas yang bertanggung } \\
\text { jawab terhadap IT }\end{array}$ \\
\hline
\end{tabular}

Berikut merupakan proses perhitung bobot kuisioner kepentingan berdasarkan kebutuhan responden. Responden adalah pihak manajemen Dinas Kependudukan dan Pencatatan Sipil Kota Denpasar pada Kepala Sub Bagian Kepegawaian dalam memastikan domain berdasarkan tingkat kepentingan manajemen, untuk proses audit serta mengevaluasi kinerja sistem informasi E-Kinerja. Tabel dibawah merupakan hasil penentuan domain COBIT 5 yang akan digunakan dalam proses audit serta evaluasi kinerja sistem [17].

Hasil tabel 4 telah dipastikan domain COBIT 5 yang digunakan. Domain COBIT 5 tersebut antara lain EDM01, EDM03, APO01, APO04, APO07, APO08, BAI02, DSS01, DSS05 dan MEA01, ada 10 domain yang tetapkan untuk digunakan pada proses audit. Hasil pengamatan dan wawancara terhadap Kepala Sub Bagian Kepegawaian Dinas Kependudukan dan Pencatatan Sipil Kota Denpasar, ditetapkan target capability model adalah 4 (Predictable Process). Target capability model yang ditetapkan selanjutnya dibandingkan pada tingkat capability model proses TI yang berjalan saat ini. Perbedaan nilai yang dihasilkan adalah 
HASIL PEMETAAN TUJUAN TI DAN DOMAIN COBIT 5

\begin{tabular}{|l|l|}
\hline Tujuan Teknologi Informasi & Domain COBIT 5 \\
\hline Penyesuaian IT dengan langkah bisnis. & EDM01 \\
\hline $\begin{array}{l}\text { Penyesuaian IT dan pendukung bisnis } \\
\text { melalui aturan dan regulasi secara } \\
\text { eksternal. }\end{array}$ & DSS05 \\
\hline Pengelolaan IT terhadap resiko bisnis & DSS01 \\
\hline $\begin{array}{l}\text { Penyampaian Pelayanan melalui IT beserta } \\
\text { keperluan bisnis. }\end{array}$ & BAI02 \\
\hline $\begin{array}{l}\text { Pendayagunaan aplikasi, informasi, serta } \\
\text { penyelesaian teknologi secara akseptable. }\end{array}$ & APO04 \\
\hline Ketepatan IT pemerosesan & EDO01 \\
\hline $\begin{array}{l}\text { Keamanan informasi, } \\
\text { informasi, infrastuktur dan pengaplikasian }\end{array}$ & APO08 \\
\hline $\begin{array}{l}\text { Kemampuan dan dukungan proses bisnis } \\
\text { melalui aplikasi secara terintigrasi dan } \\
\text { teknologi didalam proses bisnis }\end{array}$ & APO01 \\
\hline $\begin{array}{l}\text { Penyampaian IT berdasarkan aturan secara } \\
\text { internal }\end{array}$ & MEA01 \\
\hline $\begin{array}{l}\text { Kemampuan, motivasi bisnis dan petugas } \\
\text { yang bertanggung jawab terhadap IT }\end{array}$ & APO07 \\
\hline
\end{tabular}

tingkat kesenjangan (GAP) yang berjalan pada proses TI serta di evaluasi dalam menentukan saran pengembangan kedepannya [18] [19].

TABEL V

ANALISA TINGKAT KEMATANGAN

\begin{tabular}{|l|c|c|c|}
\hline \multicolumn{1}{|c|}{ Domain } & Capability Level & Target & GAP \\
\hline EDM01 & 3.75 & 4 & 0.25 \\
\hline EDM03 & 3.84 & 4 & 0.16 \\
\hline APO01 & 3.36 & 4 & 0.64 \\
\hline APO04 & 3.90 & 4 & 0.1 \\
\hline APO07 & 3.87 & 4 & 0.13 \\
\hline APO08 & 3.40 & 4 & 0.6 \\
\hline BAI02 & 3.68 & 4 & 0.32 \\
\hline DSS01 & 3.78 & 4 & 0.22 \\
\hline DSS05 & 3.47 & 4 & 0.53 \\
\hline MEA01 & 3.72 & 4 & 0.28 \\
\hline
\end{tabular}

Dari hasil analisa tingkat kematangan pada tabel 5 dapat dilihat capability level pencapaian rata-rata berada pada level 4. Untuk mempermudah melihat hasil kesenjangan antara capability level dan target pencapaian akan disajikan dalam bentuk diagram capability level. Pada gambar 4 akan ditunjukan diagram yang menunjukan kesenjangan yang terdapat dalam penerapan sistem informasi E-Kinerja pada Dinas Kependudukan dan Pencatatan Sipil Kota Denpasar.

Hasil evaluasi dan audit kinerja sistem informasi E-Kinerja pada Dinas Kependudukan dan Pencatatan Sipil Kota Denpasar, 3 domain mencapai level 3 (Established) dan 7 domain meraih level 4 (Predictable Process). Pada analisa kesenjangan terdapat GAP dengan nilai tidak terpaut jauh pada 7 domain, terdapat 3 domain APO1, APO8 Ida Bagus Agung Eka Mandala Putra : Audit Sistem Informasi E-KTP..

\section{CAPABILITY DIAGRAM}

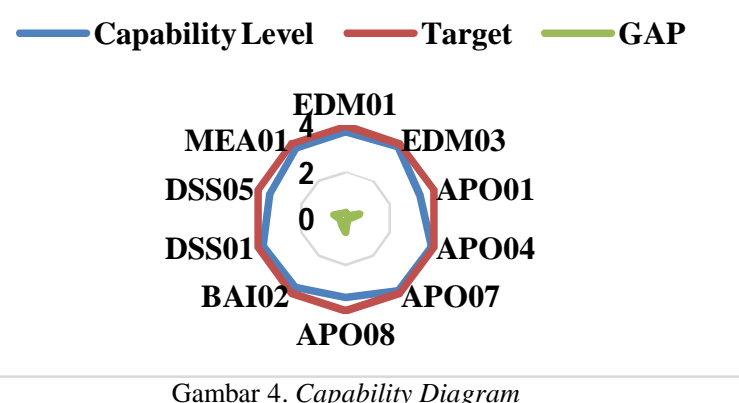

dan DSS5 terpantau jarak yang jauh. Menandakan adanya ketimpangan antara tujuan bisnis dengan tujuan TI. Berikut merupakan penjelasan mengenai hasil audit yang telah dilaksanakan.

1. EDM01 Ensure Governance Framework Setting and Maintenance mencapai nilai 3.75 (Predictable Process). Menerangkan bahwa organisasi mengawasi bagian dari tata kelola dan transparansi wewenang berserta tanggung jawab untuk mencapai tujuan perusahaan [20].

2. EDM03 Ensure Risk Optimisation meraih nilai 3.84 (Predictable Process). Mengerti serta mengkoordinasikan resiko perusahaan akan penggunaan teknologi informasi dengan dikelola dan diidentifikasi.

3. APO01 Manage the IT Management Framework mendapatkan nilai 3.36 (Established). Menyatakan Konsep manajemen perusahaan dalam pemanfaatan teknologi informasi untuk mencapai tujuan yang ditargetkan organisasi.

4. APO04 Managed Innovation mencapai nilai 3.90 (Predictable Process). Merencanakan pemanfaatan inovasi, hubunganya berkaitan dengan kebutuhan bisnis serta strategi teknologi informasi yang diinginkan. Analisa tujuan perusahaan dalam melaksanakan inovasi dibuat dengan teknologi.

5. APO07 Managed Human Resources mendapatkan nilai 3.87 (Predicatble Process). Menginformasikan pendekatan secara terstruktur untuk menentukan rekrutmen secara optimal, perencanaan, evaluasi, pengembangan sumber daya manusia (internaleksternal).

6. APO08 Manage Relationships memperoleh nilai 3.40 (Established). Memastikan hubungan dengan para pemilik kepentingan bisnis dengan formal serta transparan dan memastikan pencapaian sasaran strategis untuk merencanakan anggaran dan toleransi terhadap resiko.

7. BAI02 Managed Requirements Definition mencapai nilai 3.68 (Predictable Process).Mengidentifikasikan solusi dan kebutuhan analisis sebelum mengakuisis atau memastikan bahwa persyaratan strategi perusahaan p-ISSN:1693 - 2951; e-ISSN: 2503-2372 
berjalan selaras.

8. DSS01 Managed Operations dengan nilai 3.78 (Predictable Process). Koordinasi dan pelaksanaan kegiatan prosedur operasional dalam pelayanan TI secara internal

9. DSS05 Managed Security Services mendapatkan nilai 3.47 (Predictable Process). Menjaga informasi perusahaan untuk memastikan tingkat resiko keamanan informasi.

10. MEA01 Managed Performance and Conformance Monitoring mencapai nilai 3.72 (Predictable Process). Mengumpulkan, validasi dan evaluasi tujuan dan penyelarasan matriks perusahaan.

Berdasarkan hasil capability level diatas menunjukan tujuh domain rata-rata bernilai 3.79 mencapai target berada pada level 4 (predictable process). Menunjukan Proses yang direncanakan sebelumnya dijelaskan sekarang yang dimana beroperasi dalam batas yang ditentukan untuk mencapai hasil yang diharapkan. Namun ada tiga domain yaitu APO01, APO08 dan DSS05 rata-rata bernilai 3.41 hanya mencapai level 3 (established process). Menunjukan pengelolaan proses yang sebelumnya dijelaskan, sekarang diaplikasikan mempergunakan proses yang ditetapkan dimana dapat mencapai hasil prosesnya.

Adapun rekomendasi yang diberikan untuk mencapai capability level yang di harapkan pada domain APO01, APO08 dan DSS05 yaitu perlu dilaksanakan pemahaman konsep manajemen perusahaan dengan memanfaatkan teknologi informasi untuk mencapai tujuan perusahaan. Mengkoordinasikan hubungan dengan para pemilik kepentingan bisnis secara transparan untuk memastikan pencapaian terhadap sasaran strategis. Meminimalisir tingkat resiko terhadap keamanan informasi perusahaan.

\section{KESIMPULAN}

Hasil Analisa pada penelitian diatas, mampu memberikan kesimpulan tentang pelaksanan audit terhadap sistem informasi E-Kinerja pada Dinas Kependudukan dan Pencatatan Sipil Kota Denpasar. Audit sistem informasi EKinerja menunjukan domain EDM01, EDM03, APO04, APO07, BAI02, DSS01 dan MEA01 mencapai level 4 (Proses yang dapat diperkirakan) menandakan perencanan dari proses teknologi informasi telah mampu memberikan hasil yang diharapkan. Domain APO01, APO08 dan DSS05 meraih level 3 (Established), menandakan proses teknologi informasi telah diimplementasikan dan didefiniskan dengan baik. Adapun saran untuk meningkatkan kinerja sistem informasi E-Kinerja pada Dinas Kependudukan dan Pencatatan Sipil Kota Denpasar tentunya perlu dilaksanakan audit sistem informasi pada setiap tahunnya. Hal tersebut dapat dipergunakan sebagai bahan evaluasi dalam penerapan teknologi informasi yang dapat memberikan hasil yang optimal dalam manajemen kepegawaian.

\section{REFRENSI}

[1] Maskur, Nixon Adolong, Rusliy Mokodongan, "IMPLEMENTASI TATA KELOLA TEKNOLOGI INFORMASI MENGGUNAKAN FRAMEWORK COBIT 5 DI BPMPTSP BONE BOLANGO," J. Masy. Telemat. dan Inf., vol. 8, no. 2, pp. 109-126, 2017.

[2] P. Indonesia, Ed., KEBIJAKAN DAN STRATEGI NASIONAL
PENGEMBANGAN E-GOVERNMENT. Indonesia: Intruksi Presiden Republik Indonesia Nomor 3 Tahun 2003, 2003.

[3] PERATURAN PEMERINTAH REPUBLIK INDONESIA NOMOR 30 TAHUN $20 L 9$ TENTANG PENILAIAN KINERJA PEGAWAI NEGERI SIPIL. Indonesia: Pemerintah Indonesia, 2019.

[4] Dinas Kependudukan dan Pencatatan Sipil Kota Denpasar, PROFIL DINAS KEPENDUDUKAN DAN PENCATATAN SIPIL KOTA DENPASAR. Indonesia: Dinas Kependudukan dan Pencatatan Sipil Kota Denpasar, 2019.

[5] Pemerintah Republik Indonesia, PERATURAN PRESIDEN REPUBLIK INDONESIA NOMOR 95 TAHUN 2018 TENTANG SISTEM PEMERINTAHAN BERBASIS ELEKTRONIK. Indonesia: Pemerintah Republik Indonesia, 2018.

[6] UNDANG-UNDANG REPUBLIK INDONESIA NOMOR 43 TAHUN 1999 TENTANG PERUBAHAN ATAS UNDANG-UNDANG NOMOR 8 TAHUN 1974 TENTANG POKOK-POKOK KEPEGAWAIAN. Indonesia: Pemerintah Indonesia, 1999.

[7] UNDANG-UNDANG REPUBLIK INDONESIA NOMOR 5 TAHUN 2014 TENTANG APARATUR SIPIL NEGARA. Indonesia: Pemerintah Indonesia, 2014.

[8] ISACA, A Business Framework for the Governance and Management of Enterprise IT. 2012.

[9] A. Agung, G. Aditya, and N. P. Sastra, "Framework Pengelolaan Infrastruktur TIK di Pemerintah Kabupaten Badung," Maj. Ilm. Teknol. Elektro, vol. 17, no. 1, 2018

[10] Safriwal, "REKOMENDASI PERBAIKAN MANAJEMEN TEKNOLOGI INFORMASI PADA DINAS SOSNAKERTRANS KABUPATEN SOLOK MENGGUNAKAN COBIT 5," J. Masy. Telemat. dan Inf., vol. 8, no. 1, pp. 19-30, 2017.

[11] D. Nmae, "Evaluasi Infrastruktur Jaringan LAN OPD Pemerintah Provinsi Bali dengan COBIT 5 . 0," vol. 18, no. 2, pp. 0-7, 2019

[12] K. Budiarta, A. Iskandar, and M. Sudarma, "Audit Information System Development using COBIT 5 Framework (case Study: STMIK STIKOM Bali) Komang," Int. J. Eng. Emerg. Technol., vol. 1, no. 1, pp. 1-5, 2016.

[13] B. Gamaliel et al., "KELOLA TEKNOLOGI INFORMASI MENGGUNAKAN COBIT 5 PADA PEMERINTAH SULAWESI UTARA," E-Journal Tek. Inform., vol. 11, no. 1, pp. 1-8, 2017.

[14] A. Sumichan, I. M. G. Yudiyana, and I. M. Sudarma, "Audit with COBIT 5 Framework Focused on DSS Domains," Int. J. Eng. Emerg. Technol., vol. 3, no. 2, pp. 67-71, 2018.

[15] S. Ranggi Praharaningtyas Aji, "PENILAIAN TATA KELOLA TEKNOLOGI INFORMASI PADA DINAS KESEHATAN KABUPATEN BANYUMAS MENGACU PADA KERANGKA KERJA COBIT 5," J. Pro Bisnis, vol. 12, no. 2, pp. 1-12, 2019.

[16] M. Hendayun, "Tata Kelola Teknologi Informasi pada Perguruan Tinggi Menggunakan Control Objective for Information \& Related Technology ( COBIT ) 5," J. Tek. Inform. dan Sist. Inf., vol. 3, no. April, pp. 206-216, 2017.

[17] D. Krisnandari, D. M. Wiharta, and N. P. Sastra, "Penerapan Teknologi Informasi dalam Reformasi Birokrasi pada Bidang Pendidikan," Maj. Ilm. Teknol. Elektro, vol. 18, no. 2, 2019.

[18] S. D. Rehatta and A. D. Manuputty, "Measurement of the Maturity Level of IT Governance in Implementing Personnel Management Information System Using the MEA Domain COBIT 5 Framework In Regional Personnel, Education and Training Agency," J. Inf. Syst. Informatics, vol. 1, no. 2, pp. 123-135, 2019.

[19] S. Nella, S. Berlianna, and A. R. Perdanakusuma, "Evaluasi Tingkat Kapabilitas Sumber Daya Teknologi Informasi Pada Institut Teknologi Nasional Malang Menggunakan Kerangka Kerja Cobit 5," J. Pengemb. Teknol. Inf. dan Ilmu Komput. Univ. Brawijaya, vol. 2, no. 10, 2018. 